\title{
The Role of OPEC in Reducing Oil Prices under International Law: The 2014 Downfall and Today's Relevance
}

\author{
Deymah Alweqyan*
}

Fluctuation in the price of oil has been an international concern for decades, because oil is the primary export and main economic driver for many States. OPEC as an international organization is practicing its role in controlling oil prices and oil market under the rules and norms of international law. In 2014, the price of oil decreased tremendously in a way that shocked the international market. OPEC tried to stem the losses and prevent prices from falling even further, and tried to facilitate international law in the current crisis. World markets were further shocked when OPEC announced that it would not cut production, and that the market would be supplied by the usual average amount of oil exports. In contrast, WTO cut its global trade in an attempt to shore up prices in the international markets, since low oil prices affected international trade as well. In this article, I analyze the oil crisis that hit the world from 2014 to the early year of 2016 period, and the role of international organizations such as OPEC and WTO in facing international economic crises, as well as the role of international politics to assure the implementation of law.

\section{Keywords}

OPEC, Oil Price, WTO, Kuwait, Saudi Arabia, Russia, United States

Over the years, the global oil and gas industry has gone through many cycles and changes that have required the industry to adapt

* Professor of International Law at Kuwait University Law School; Legal Advisor of Kuwait Oil Minister. LL.B./ LL.M. (Kuwait Univ.), Ph.D. (Penn State Univ.). ORCID: http://orcid.org/0000-0002-7300-9538. The author may be contacted at: dr.dema.alwugyan@gmail.com/Address: Kuwait University, Shuwaikh, Jamal Abdulnasser road, Kuwait. All the websites cited in this article were last visited on May 8, 2020. 
and evolve. There is no doubt that the last nine months [starting June 2014] has been one of those intermittent periods of volatility after several years of stability.

Abdullah El-Badri, OPEC Secretary-General ${ }^{1}$

\section{Introduction}

Fluctuation in the oil price has been an international concern for decades. Oil is the primary export and main economic driver for many States, and thus oil prices can determine whether the economy remains stable or is thrown into chaos. Oil has experienced periods of particularly high prices in 1973, 1980, 1990, 2003, and 2009. In contrast, oil declined in value, and prices fell down tremendously in 2014 . $^{2}$

The breathtaking oil price decrease of 2014 shocked the global economy. The Organization of Petroleum Exporting Countries ("OPEC") sought to increase oil prices because it would not only effect States but also upstream and downstream oil companies. OPEC announced that it would not decrease production to preserve streamlined movement for global oil markets with the assurance of a slow increase in prices after a few months. ${ }^{3}$

Moreover, Iran and Russia ${ }^{4}$ accused Saudi Arabia of manipulating oil prices to achieve a particular agenda. Indeed, Saudi might have sought to break the RussianSyrian-Iranian alliance as it strengthened due to the Syrian conflict in 2012; thus, it could have harmed their economies. However, Saudi Arabia might also have wanted to prevent American shale producers from becoming competitors in the oil market. Regardless, Saudi Arabia wanted to continue leading OPEC and dominating the

1 Speech by OPEC Secretary-General to the 19th Middle East Oil \& Gas Conference, Ministerial Panel Session, Manama, Bahrain (Mar. 8, 2015), available at http://www.opec.org/opec_web/en/2973.htm.

2 L. Kilian, Oil Price Volatility: Origins and Effects, WTO Report (2010), available at https://www.wto.org/english/res e/publications_e/wtr10_forum_e/wtr10_kilian_e.htm.

3 T. Hirst, OPEC Votes Not To Cut Production, Oil Prices Plummet, Bus. Inside, Nov. 27, 2014, available at https:// www.businessinsider.com/opec-votes-not-to-cut-production-oil-prices-plummet-2014-11.

4 J. Dettmer, Iran Accused Saudi Arabia of Oil Conspiracy, VOA, Jan. 6, 2015, available at: https://www.voanews. com/middle-east/iran-accuses-saudis-oil-conspiracy See also Saudi Arabia Manipulates Oil Price for Political Gains: Russian Official, Press TV, Oct. 13, 2014, available at https://www.konfrontasi.com/content/english/saudi-arabiamanipulates-oil-price-political-gains-russian-official; T. Hirts, Saudi Arabia's Oil Price 'Manipulation' Could Sink the Russian Economy, Bus. INsidE, Oct. 13, 2014, available at http:/www.businessinsider.com.au/russia-saudi-arabia-andoil-prices-2014-10. 
global oil trade. ${ }^{5}$

The primary purpose of this research is to analyze the role of OPEC in setting production and controlling reduction of oil prices under the political or economic influence. This paper is composed of five parts including Introduction and Conclusion. Part two will overview the swings in oil prices over the past several decades Part three will highlight the role of OPEC as an international organization responsible for oil price stability while comparing with the WTO. Part four will tackle the strategy of Saudi Arabia in manipulating international oil prices and the reasons behind the 2014 reductions.

\section{Background of Fluctuating Oil Prices}

Crude oil is one of the main energy sources in the world. Oil prices have fluctuated for different reasons. For example, international demand drives swings in prices, which is connected to the changes implemented by OPEC and non-OPEC oil producing countries. Those changes can be related to production, prices, and trade and have helped shape the international demand of oil for many years. ${ }^{6}$ Oil prices were relatively lower than today from 1948 to the 1960s (USD 2.50 to USD $3.00 \mathrm{P} /$ B); the price of oil then increased to an average of USD $24 \mathrm{P} / \mathrm{B}$. At that time however, this was not a large concern because many Middle Eastern countries, especially in the Gulf Area, were actively exploring new oil wells and exporting their products.

The establishment of OPEC in 1960 had a major impact on the oil trading market with five founding members: Iran, Iraq, Kuwait, Saudi Arabia, and Venezuela. OPEC ushered in a new era of oil energy trade. In 1973, OPEC, led by its Arab Member States, placed an oil embargo on any State that supported Israel because Egypt and Syria had entered the Yom Kippur war against Israel. ${ }^{8}$ Consequently, many Western States were unable to import oil from the Middle East. According to OPEC, oil production would be cut by 5 percent each month until Israel voided its occupation of Palestine and acknowledged it as an Arab territory. ${ }^{9}$ The US, the UK, France, and

5 C. Baumeister \& L. Kilian, Understanding the Decline in the Price of Oil Since June 2014, 501 Fin. Stud. 1 (2014).

6 M. Horn, OPEC's Optimal Crude Oil Price, 32 Energy Pol'y 271 (2004).

7 J. Hamilton, Historical Oil Shocks, U.C. San Diego Dept. of Economics, (2010), at 9, available at https://econweb. ucsd.edu/ jhamilto/oil_history.pdf.

8 A. Rabinovich, The Yom Kippur War: The Epic Encounter that Transformed the Middle East 12 (2007). See also S. Dunstan, The Yom Kippur War: The Arab-Israeli War of 1973, 117 (2007).

9 OPEC Enacts Oil Embargo, History: OCTOBER 17, 1973, available at http://www.history.com/this-day-in-history/opec- 
Germany were disadvantaged by the embargo. The US experienced particularly serious economic consequences and energy crisis due to the lack of access to foreign oil. ${ }^{10}$ Oil prices increased to more than USD 12 P/B by the end of 1974 . As a result, the embargo shifted control of oil prices from the US to OPEC.

Oil prices changed in 1980s again for the war between Iraq and Iran as oil production in both countries were decreasing to $800,000 \mathrm{~B} / \mathrm{D}$; therefore, OPEC countries had a 10 percent decrease in production pushing oil prices higher. ${ }^{11}$ Iran has still not recovered from that crisis-its production is only two-thirds of levels during the time of Shah Mohamed Reza Pahlavi in the 1970s. Iraq recovered more quickly than Iran. However, its oil production remains below one million B/D because of further conflicts with Iran and the Kuwaiti invasion in $1990{ }^{12}$

Saudi Arabia played a big role in stabilizing oil prices. It has been working actively since the 1980s with other OPEC members to fight the increasing production of the American shale oil. ${ }^{13}$ By 1985, Saudi Arabia was a major decision-maker in OPEC on price-setting and restrictions on output. It would sometimes take occasional independent actions such as doubling its prices for more than two financial quarters to offset its loss and gain profits for the 1973 embargo. ${ }^{14}$ Saudi Arabia also used to cooperate with the OPEC members to increase or decrease oil production when necessary. It may change its stance in accordance with the circumstances and then seek OPEC's support. In other cases, however, Saudi Arabia tended to increase production to offset the interruptions such as during the Iraq-Iran conflict (1980-81), Iraq's invasion of Kuwait (1990), the US invasion of Iraq (2003), the global financial crisis (2008-09), and the Libyan conflict (2011). ${ }^{15}$

In 2014, Saudi Arabia took a strong stance on international events including the Syrian conflict, the Russian-Syrian-Iranian alliance, and US shale oil production.

enacts-oil-embargo.

10 US Dept. of State, Oil Embargo 1973-1974 (Oct. 31, 2013), available at https://history.state.gov/milestones/1969-1976/ oil-embargo.

11 F. Praussello, Sustainable Development and Adjustment in the Mediterranean Countries Following the EU ENLARGEMENT 137-8 (2006).

12 J. Williams, Oil Prices History and Analysis, Wtrg Economics (2011), available at http://www.wtrg.com/prices.htm.

13 J. Griffin, OPEC Behavior: A Test of Alternative Hypotheses, 75 Am. Econ. Rev. 954 (1985). See also J. Smith, Inscrutable OPEC? Behavior Tests of the Cartel Hypothesis, 26 ENERGY J. 75 (2005); R. Kaufmann, et al., Determinants of OPEC Production: Implications for OPEC Behavior, 30 ENERGY ECON. 348 (2008).

14 See, e.g., P. Geroski, et al., A Model of the Crude Oil Market Conduct Varies, 97 Econ. J. 77 (1987); D. Gately, Do Oil Markets Work? IS OPEC Dead? 14 Ann. Rev. Energu. 95 (1989); J. Griffin \& W. Neilson, The 1985-1986 Oil Price Collapse and Afterwards: What Does Game Theory Add? 32 Econ. InQ. 543 (1994).

15 K. Alkhathlan, et al., Analysis of Saudi Arabia's Behavior within OPEC and the World Oil Market, 64 ENERGY PoL'Y 209 (2014). 
These circumstances contributed to a precipitous drop in oil prices to a level below USD 38 P/B down from more than USD 115 P/B. This had a significant impact on international oil market. Saudi Arabia's main goal is to lead OPEC to maintain the stability of oil prices regardless of any political or economic condition of the international community. ${ }^{16}$ It wanted to be the ultimate controller of the world oil market. James Smith notes: "There is evidence to indicate that Saudi Arabia has acted as a 'leader' or dominant firm within the cartel."17

\section{International Organizations Maintaining Stability in Oil Price and Trade}

\section{A. OPEC's Role in Stabilizing Oil Prices}

The main purpose and ultimate role of OPEC is to coordinate and unify the oil policies of its member states to reach the best means of their interests by stabilizing oil prices and controlling international production to prevent any unnecessary fluctuation. ${ }^{18}$ The increasing demands on crude oil in the 1960s pushed petroleumproducing States to organize the process of production and prices. These States tried to restore the prices in mid-1960 to prevent major oil refining companies of the West from controlling the prices. In the beginning, however, it was difficult for OPEC to stand against those oil refineries so that it continued to be second level until the mid1970s. ${ }^{19}$

OPEC adopted a series of agreements between 1971 and 1973 after it held control over the market ${ }^{20}$ with increasing inflation (Tripoli I, Tehran, Tripoli II, Geneva I \& II). ${ }^{21}$ By balancing the percentage of production, OPEC succeeded in maintaining stable oil prices by the mid-1980s. As OPEC started to control the prices, the era of cheap oil was finished..$^{22}$ One of OPEC's important roles was to monitor, forecast, and

16 D. Alweqyan, Selectivity in International Law Enforcement ch. V (2015). See also R. Cairns \& E. Calfucura, OPEC: Market Failure or Power Failure, 50 ENERGy PoL'y 571-5 (2012).

17 Smith, supra note 13 , at 75.

18 OPEC Statute, The Organization of the Petroleum Exporting Countries, art. 2 (1965).

19 Md. Ahrari, OPEC: the Falling Giant 3-5 (1986).

20 OPEC Statute art. 15(1).

21 Id.

22 C. Y. Lin \& Abdul Siddique, Recent Patterns of Inflation in the Non-Oil Developing Countries, 28 Fin. \& Dev. 28-31 (1978). 
analyze any changes or developments in the energy and petrochemical industries; observe international demands; and evaluate economic and financial matters of significant interest mainly for member States related to international petroleum industry. ${ }^{23}$

Even since the early years, OPEC has been a dominant decision-maker and controller of global oil price. Decisions by OPEC are being adopted 'unanimously' by all member States. When a decision is objected by any member, it does not get adopted. This underscores the importance of each member's stance in protecting their policies and production. Moreover, OPEC can assure every members' right of voting. They stated that even those who did not attend an OPEC meeting may object to the decision adopted by notifying the Secretariat of OPEC about their objection, which can often suspend the decisions. ${ }^{24}$

However, Saudi Arabia exclusively dominates the decision-making process in OPEC. It pressures the other members to agree to its policies in production, which contrasts with the OPEC Statute where all member States enjoy sovereign equality with one vote. ${ }^{25}$ Each member can object to production policies. Legally they might do so, but politically they feel pressured by Saudi Arabia to concur with the Saudi position. For instance, many OPEC members such as Venezuela wanted to cut production in 2014 to raise oil prices, but Saudi Arabia pushed toward not cutting output. This led OPEC to adopt a unanimous decision into continuing the production levels.

Thus, one may wonder why Saudi Arabia controls the decision-making process in OPEC if all member States enjoy equal position, equal vote, and the right to object and suspend a decision. The OPEC Statute suggests that OPEC established not only equal votes and positions but also an equal amount of contribution. ${ }^{26}$ This prevents the OPEC States from having an advantage over the others. The Saudi situation shows that it depends on the lobby inside of OPEC. Saudi has the ultimate support of the Gulf Cooperation Council ("GCC") States. The GCC always supports the Saudi perspective and pushes toward the decision it desires. Saudi also uses its position as the largest oil exporter country to press other members into adopting a decision. Moreover, Saudi is a leader of Arab States, enjoying a good international relation with many OPEC and non-OPEC oil producing countries around the world. Thus, by maintaining these relations, Saudi can adopt any decision that suits its interests with 
the support and acceptance from these countries.

Since its establishment, OPEC has witnessed several periods reduced oil prices mostly due to political rather than economic reasons. The wars and conflicts in the Middle East over the past three decades have strongly influenced the oil market. The Iran-Iraq war of the 1980s destabilized oil prices due to reduced production by the two of the largest OPEC members, which led to higher global demand for oil, because, at that time, oil production should have maintained above 5 million B/D.

When Iraq invaded Kuwait in 1990, the UN Security Council imposed economic sanctions on Iraq, which prohibited it from exporting goods and petroleum resources, and importing weapons and large equipment. ${ }^{27}$ The Security Council Resolutions 687 and 661 established this embargo stating that member states shall prevent "the import into their territories of all commodities and products originated by Iraq or Kuwait [...] to promote the export trans-shipment of any commodities or products from Iraq or Kuwait." ${ }^{28}$ Hundreds of oil wells were destroyed, and Kuwait could not fully produce until the fires of wells were extinguished, which took nearly a year. This reduction strongly affected Kuwait's budget and global markets due to a shortage production. All of these factors led to a reduction in OPEC's oil production, which caused an increase in oil prices. Eventually, many States such as China demanded more oil from those countries-especially Saudi Arabia. ${ }^{29}$

The oil market has changed tremendously in recent decades. State-owned oil companies produced 89 percent of the world's oil supplies until the turn of millennium. Since then, their oil supplies have dropped to 60 percent of the global output controlling more than 70 percent of proved reserves. That led to an increase in financial traders such as hedge funds, banks, commodity index funds, and others parties to support the oil market. Their participation went from 33 percent in 2004 to 50 percent in $2008 .^{30}$ These entities process their trade directly between the 20 largest oil companies of the world, while oil producers decrease during the same period from 31 percent to 15 percent. $^{31}$ This situation affected oil market with financial risks, geographical conflicts, volatility of oil prices, and politics. ${ }^{32}$ OPEC's dominance in the

27 S.C. Res. 687, U.N. Doc. S/ RES/687 (Apr. 3, 1991).

28 S.C. Res. 661, U.N. Doc. S/ RES/661 (Aug. 6, 1990).

29 R. Block, Kuwaiti Oil Wells, in Crimes of War 2.0: What the Public Should Know, 73 (A. Dworkin ed., 2007). See also J. Seacor, Environmental Terrorism: Lessons from the Oil Fires of Kuwait, 10 Am. U. J. InT’L L. \& PoL'y 481 (1994).

30 Buyuksahin, et al., Fundamentals, Trader Activity, and Derivative Pricing, CFTC (2008), available at https://cftc.gov/ stellent/groups/public/@newsroom/documents/file/marketreportenergyfutures.pdf.

31 J. Smith, World oil: market or mayhem?, 23 J. Eco. Pres. 145 (2009).

32 Id. at 145-6. See also Yue-Jun Zhang \& Yi-Ming Wei, The Dynamic Influence of Advanced Stock Market Risk on 
oil market resulted in increasing chances of economic crises due to the competition between OPEC members and non-OPEC members; between OPEC and oil-refining companies; and between OPEC and oil demanders. This constantly affects oil's volatility and inflation. ${ }^{33}$

The price of oil moved freely in the global market before 2000. The OPEC announced a fixed price range of USD 22-28 P/B on March 28, 2000. This was to prevent the OPEC members, especially Saudi Arabia, from unilaterally pricing oil based on its interests and breaching the OPEC statutes. ${ }^{34}$ Thus, producing States should follow OPEC's strategy in pricing and producing to assure the long-term stability of the oil market. ${ }^{35}$ However, the International Energy Agency ("IEA") showed that the non-OPEC oil producing countries had an excess in demand of 35 million P/B by $2013 .^{36}$ They were heading to control the market by 59.8 percent of world oil production, but the oil crisis finally hit the economy in $2014 .^{37}$ According to James Hamilton who investigated the factors behind the dominance of OPEC in controlling oil prices and production, oil-exporting countries are seeking to achieve their benefits in conformity with stabilizing global oil and trade markets in a way that does not affect other economies. ${ }^{38}$

Raymond Li disagreed with this idea stating that OPEC must not dominate the process of price and production to reach economic stability. There should be a causality of flow from OPEC production to oil prices and from oil prices to non-OPEC production: This relationship leads balance in the production between OPEC and non-OPEC producers. Li concluded that it is no longer acceptable to consider OPEC as the ultimate oil firm but other players should participate. However, many OPEC members were moving solely in their output level without the rest of the members such as Nigeria and Venezuela that merged with the remaining OPEC production at a level of 5 percent. This indicates that OPEC was challenged in setting production levels between its members, which is in contrast to article 33 of the Statute (OPEC is responsible for drawing the general policy of production in favor of members'

International Crude Oil Return: An Empirical Analysis, 11 Q. Finance 967 (2011); Gang Wu \& Yue-Jun Zhang, Does China Factor Matter? An Econometric Analysis of International Crude Oil Prices, 72 EnERGy PoL'y 78 (2014).

33 Hassan Ghassan \& Hassan Al Hajhoj, Long Run Dynamic Volatilities between OPEC and Non-OPEC Crude Oil Prices, 169 Applied ENergy 384 (2016).

34 OPEC Statute, art. 3.

35 Williams, supra note 12.

36 IEA, Oil Market Report: Annual Statistical Supplement, (2013), available at https:/www.iea.org/data-and-statistics/ data-tables/?country=WORLD\&energy=Oil\&year=2013.

37 Ghassan \& Al Hajhoj, supra, note 33, at 385.

38 J. Hamilton, Understanding the Crude of Oil Prices 7-8 (Nat'l Bureau of Econ. Research Working Paper No. 14492, 2008). 
interests). ${ }^{39}$

The 2014 oil price crisis pushed OPEC to hold an urgent meeting ${ }^{40}$ in Vienna on November 27, 2014 to find a solution to the huge drop in oil prices. At this meeting, OPEC unexpectedly refused to cut production and insisted on continuing to provide the market with the same average level of production that it had before the price declined. This decision was strongly supported by Saudi Arabia and the rest of the GCC countries. ${ }^{41}$ OPEC stated that there was no reason to panic because the decrease in price occurred when the market was saturated with crude oil production. Moreover, OPEC assured the global markets that it was working to increase oil prices to reach stable economic standards for the OPEC oil suppliers. ${ }^{42}$ OPEC's plan seems to have worked until January 2016 when prices declined below the 2014 crisis range (GCC's oil was USD 19 P/B). The international community was stunned by the huge reduction in prices and assumed that the oil market would enter a new phase with most States desiring alternative energy such as more sustainable bio-fuel, solar, and nuclear. Such a shift has been adopted by modern industries to protect the environment with green business practices. As these alternative energy sources are often uneconomical and politically difficult, ${ }^{43}$ however, there are calls for a solution to manage this matter by fixing three major problems that affect oil prices. First, decreased wages for many consumers are needed. Second, one should focus on world debts that are no longer increasing (this is not an issue for consumers who have financial stability). Finally, the dollar should be lowered relative to other currencies. By applying those solutions, oil prices may be lower for a while until the market is stable by erasing those previous problems. ${ }^{44}$

\section{B. OPEC and WTO}

Both OPEC and the World Trade Organization ("WTO”) suffered negative impacts from low oil prices including Chinese and American markets. There were effects

39 R. Li, The Role of OPEC in the World Oil Market, 9 InT'L J. Bus. \& Econ. 83-5 (2010).

40 OPEC Statute art. 12.

41 K. Hjelmgaard, Oil Prices Plummet as OPEC Decides Against Output Cut, USA Today, Nov. 27, 2014, available at http://www.usatoday.com/story/money/markets/2014/11/27/opec-vienna-meeting/19570473.

42 P. Armstrong, OPEC Meeting Could Reveal Fractures in Oil Cartel, CBC NEws, Nov. 27, 2014, available at http:// www.cbc.ca/news/business/opec-meeting-could-reveal-fractures-in-oil-cartel-1.2851134; See also Oil Prices plunge after OPEC Meeting, BBC News, Nov. 28, 2014, available at http://www.bbc.com/news/business-30223721.

43 S. Ross, What Are the Main Substitutes for Oil and Gas Energy?, Investopedia (Apr. 5, 2010), available at https:// www.investopedia.com/ask/answers/060415/what-are-main-substitutes-oil-and-gas-energy.asp.

44 G. Tverberg, A Lasting Solution to Low Oil Prices, OIL Price.com, Apr. 19, 2016, available at https://oilprice.com/ Energy/Energy-General/A-Lasting-Solution-To-Low-Oil-Prices.html. 
on the trade of goods in many other markets including the European and the Asian markets that depend on oil revenue, e.g., clothes, Vaseline, coloring tablets, medicines, and agricultural fertilizers, which are the most used sectors of oil products, through the use of ammonia that is found in oil ${ }^{45}$ Thus, it is critical to balance oil prices and global trade because each one affects the other's stability. Both were affected by other factors, which led to a reduction in oil and trade such as the political crises in Ukraine, Libya, Egypt, and Syria. There were economic crises such as the reduction in the value of the Euro in 2014. Also, the reduction in world oil prices seriously decreased international export/import business. ${ }^{46}$

Oil prices did not explicitly have agreements with WTO because all commodity trade agreements focused on cutting tariffs and cancelling restrictions to importing countries, but oil trade only reduced tariffs a small percentage, and that was almost exclusively in Japan and the US. ${ }^{47}$ The absence of an agreement regulating oil trade does not mean that the provisions of the General Agreement on Tariffs and Trade ("GATT") do not apply on oil. There is no explicit article excluding oil trade from GATT or prevent any country from exporting oil even for non-OPEC members. The main principle is to liberate foreign trade from quantitative restrictions. However, the absolute application of this principle can influence decisions in oil-producing countries, and the policy of OPEC is sometimes inconsistent with the WTO agreements by increasing oil production leading to more exports with thus lower prices. Reducing oil production leads to a reduction in exports and hence to price increases. Such a relationship is prohibited in this system, so that oil-producing countries cannot control their resources as they wish leading to damage to their commercial and financial interests. To prevent falling into this dilemma, such countries should follow the exceptions of the principle of liberation by the WTO agreements, e.g., observing international demands in products. Such a strategy can lead to the best possible freedom in setting appropriate policies including reduced exports. ${ }^{48}$

The exception in Article 20 of GATT permits countries to take all necessary measures to conserve their exhaustible natural resources. This strongly applies in regulating oil and natural gas trade because their exports represent three quarters

45 A. Husain, et al., Global Implication of Lower Oil Prices, IMF Staff Discussion Note (July 2015), at 15.

46 See WTO Cuts Global Trade Outlook, DW News, Apr. 14, 2015, available at http://www.dw.de/wto-cuts-global-tradeoutlook/a-18380356. See also WTO Cuts 2015 Global Trade Growth outlook to 3.3\% from 4\%, Bus. InsiDE, Apr. 14, 2015, available at https:/www.bangkokpost.com/world/528167/wto-cuts-2015-global-trade-growth-outlook-to-3-3from-4.

47 Y. Selivanove, Research Handbook on International Energy Law ch. 11 (2014).

48 GATT arts. 20-21 (1947). 
of the exports of exhaustible resources in the world. ${ }^{49}$ Therefore, any oil-producing country can control its production according to what it considers appropriate to avoid rapid exhaustibility, i.e., it can reduce its exports by reducing its production. However, each country's right to reduce its exports according to this exception is subject to two conditions. The first is to respect the principle of non-discrimination between States; thus, oil exports to a country cannot be reduced without another but the reduction must include all importing countries. The second condition is to preserve the internal consumption of petroleum products because the reduction in exports may occur with a rise in domestic consumption: This can be interpreted as a way to raise prices in the global market and waste natural resources-not preserving them from being exhausted. Therefore, the decline in exports must be commensurate with the reduced production and consumption. This exception is the basis on which oil countries should rely on when deciding to reduce their exports and avoid any collapse in their economy. ${ }^{50}$

\section{Role of Saudi Arabia and the Decline of Oil Prices in 2014}

Prior to 2014, the oil price had been stable for a long time. Prices were as high as USD 115 P/B for years until June 2014 when the international economy was shocked by a huge reduction in oil prices. The oil market fell by more than 40 percent and kept falling until it reached USD 40 P/B in August 2014..$^{51}$ After six months of steady prices, the prices slightly increased by March 2015 resting at USD 50 P/B. There were another two months of steady prices, and oil then declined rapidly once to below USD 20 P/B by February 2016. This led to problems for some States such as Iran and Russia. $^{52}$

Saudi Arabia was accused of manipulating prices for its political and economic profit. However, Saudi Arabia defended itself declaring that it was the most affected

49 T. Josling, The Oxford Handbook on The World Trade Organization: New Trade Issues in Food, Agriculture and Natural Recourses 668 (2012).

50 S. Nawosh, Oil exports to the World Trade Organization, JAZEERA J. 6-8 (2015).

51 E.L., Why the Oil Price is Falling, Economist, Dec. 8, 2014, available at http://www.economist.com/blogs/economistexplains/2014/12/economist-explains-4.

52 M. Stocker, et al., What Triggered the Oil Price Plunge of 2014-2016 and Why It Failed to Deliver an Economic Impetus in Eight Charts, World Bank Blogs (Jan. 18, 2018), available at https://blogs.worldbank.org/developmenttalk/ what-triggered-oil-price-plunge-2014-2016-and-why-it-failed-deliver-economic-impetus-eight-charts. 
country due to a reduction in oil prices. ${ }^{53}$ These declining oil prices happened at a time when multiple events were occurring in the world. The global financial crisis that hit the world resulted in a sharp price volatility for financial and commodities markets. This led to oil prices dropping to less than USD $30 \mathrm{P} / \mathrm{B}$ in the second half of 2008 due to the production cut seeking a balance between oil supply and demands. This led to a sudden jump in November 2008 until it recovered by early 2009 at USD $100 \mathrm{P} / \mathrm{B}^{54}$ There was then continued stability until the Middle East witnessed violent protests and revolutions called Arab Spring. This unrest changed many governments and shocked the economic stability of many countries such as Egypt, Tunisia, and especially Libya (one of the largest oil-exporting countries in the world). In turn, oil prices become volatile and impacted Russia and Iran as well as their allies.

Furthermore, the EU suffered economic problems starting in 2014 including a low rate of exchange between the Euro and the US dollar in addition to a serious economic crisis that almost led to the bankruptcy of Greece. The EU in turn injected liquidity into Greece to stabilize its economy. ${ }^{55}$ However, it is difficult to pinpoint one cause for the large drop in prices.

\section{A. Effect of Oil Prices to Some GCC States}

The six oil ministers of the GCC held a meeting in Kuwait on September 11, 2014. The ministers expressed their concerns about a crash in oil prices, and they were fully confident that it would not affect their income or economic stability. ${ }^{56}$ Oil is the main source of export in the GCC States with 90 percent of total revenues (considered in the aggregate) close to USD 729 billion in $2016 .^{57}$

The GCC stance toward the decrease in oil prices was meant to reassure the oil market of the ability to increase oil prices and spread confidence in the global market. Ali Al-Nuaimi, the former Saudi oil minister stated: "Saudi oil policy has remained constant for the past few decades, and it has not changed today." ${ }^{, 58}$ He suggested

53 Qiang Ji \& Jian-feng Guo, Oil Price Volatility and Oil-Related Events: An Internet Concern Study Perspective, 137 APPLIED ENERGy 258 (2015).

54 Id.

55 Alweqyan, supra, note 16, ch. IV.

56 Kingdom of Hahrain National Gas Authority, Minister of Finance, Minister in Charge of Oil and Gas Affairs Participates in GCC Oil Ministers Meeting (Sept. 11, 2014), available at http://noga.gov.bh/noga/news.aspx?id=778.

57 MEE and Agencies, GCC Warned that Falling Oil Prices Could Leave them with Budget Deficits, MidDLE E. EYE NEws, Oct. 25, 2014, available at http://www.middleeasteye.net/news/gcc-131306376. See also IMF, Annual Meeting of Ministers of Finance and Central Bank Governors, Diversifying Government Revenue in the GCC: Next Steps (2016), available at https://www.imf.org/external/np/pp/eng/2016/102616.pdf.

58 See Saudi oil Minister Denies Crude Price War, DaILy MaIL, Nov. 12, 2014, available at http://www.dailymail.co.uk/ 
that the GCC must adopt a mutual decision with OPEC not to cut output in a move to contain the consequences of the crisis. Adopted in November 2014, ${ }^{59}$ this decision raised many questions about Saudi oil policy including whether Saudi Arabia pushed for this decision to harm Iran for its interference in the region or whether the decision was based on economic reasons like hitting the US shale oil production. This was especially true because Saudi Arabia had used oil before as a pressuring tool (oil embargo of 1973). ${ }^{60}$

\section{The role and reasons for Saudi Arabia's reduction in oil prices}

Saudi Arabia is the world's biggest oil exporter. It used to produce 10 million B/D when the crisis hit in 2014 which was one-third of OPEC's total production. ${ }^{61}$ With such production capacity, Saudi Arabia usually controls the oil price in the global oil markets. However, low oil prices also affected the Saudi economy because it completely relies on oil revenue. Thus, the Saudis have tried to diversify the economy with other sources of income to avoid reductions in the public budget.

Saudi Arabia also refused to cut its output to increase prices and continued selling oil at lower prices. ${ }^{62}$ It claimed that oil price reductions were "no cause for alarm." ${ }^{, 3}$ In August 2015, Saudi Arabia led another OPEC meeting and prevented cuts in oil production. ${ }^{64}$ However, OPEC agreed to cut its production up to 400,000 $\mathrm{B} / \mathrm{D}$ following the final OPEC recommendations that its members attempt to reduce production in September that year. Saudi Arabia raised its exports an additional 100,000 B/D, thus it reduced its output by only 300,000 B/D since the crisis of 2014 . $^{65}$

Saudi investor Prince Al-Waleed bin Talal harshly criticized the Saudi government and the former Minister of Oil, Ali Al-Nuaimi, for this stance. He sent an open letter to the official leaders of Saudi Arabia. ${ }^{66}$ In his letter, Prince Al-Waleed argued that

wires/afp/article-2831983/Saudi-oil-minister-denies-crude-price-war.html.

59 See Cabinet briefed on Result of GCC Oil Ministers' Meeting, KuwaIt News AgenCY, Sept. 15, 2014, available at http:/www.kuna.net.kw/ArticleDetails.aspx?id=2397361\&language=en.

60 Some may argue that Saudi Arabia has not used oil as a weapon or a political tool since the embargo. However, it still uses it as a negotiation tool for its foreign policy or international relations.

61 E.L. supra note 51.

62 B. Hubbard \& C. Krauss, As Oil Prices Plummet, Saudi Arabia Faces a Test of Strategy, N. Y. Times, Oct. 15, 2014, available at $\mathrm{http} / /$ www.nytimes.com/2014/10/16/world/middleeast/as-oil-prices-plummet-saudi-arabia-faces-a-test-ofstrategy.html?_r=0.

63 See No Cause for Alarm, Saudi Gazette, Sept. 11, 2014, available at http://www.saudigazette.com.sa/index.cfm? method=home.regcon\& contentid=20140912217931.

64 Md Bazzi, Saudi Arabia is Playing Chicken with its Oil, Reuters, Dec. 15, 2015, available at http://blogs.reuters.com/ great-debate/2014/12/15/saudi-arabia-is-playing-chicken-with-its-oil.

65 See Crude Falls to Lowest Level in Two Years, Fox Bus., Oct. 10, 2014.

66 The Open Letter from H.R.H. Prince Alwaleed bin Talal to the Saudi Minister of Oil, Alwaleed, Oct. 13, 2014, 
Saudi Arabia's government should take serious measures to avoid an economic crisis. He also criticized the language used by Al-Nuaimi when he (the latter) publicly assured the world that there was nothing to worry about, because oil prices had been going up and down for many decades ${ }^{67}$ and Saudi Arabia could manage any economic crisis. Those declarations have not satisfied Saudi investors because of the manipulation of oil prices by the Ministry of Oil in spreading lies and illusions and not illustrating the impacts and results of low oil prices on the Saudi economy. Indeed, Saudi Arabia could incur a budget deficit if the situation (low oil prices) continued. $^{68}$

The actions of Saudi Arabia have been referred to as a game. ${ }^{69}$ This game may be political or economic. ${ }^{70}$ Thus, some important questions might be raised: Why does Saudi Arabia manipulate oil prices? Does Saudi Arabia have a hidden agenda? And, if so, what is that agenda? Is Saudi Arabia seeking revenge against Iran or is their motivation simpler than revenge? Is Saudi Arabia protecting its position as the world's leading supplier of oil from threats posed by the US shale oil companies?

Saudi Arabia may be motivated to keep oil production high even if that allows low oil prices to persist for Russia and Iran. Saudi Arabia cannot put political pressure on Russia because of Russia's position in the UN Security Council and its stances toward the Syrian conflict in 2012 and the Al-Assad regime. Russia is considered the first ally of the Syrian regime with close international relations; it completely refused to adopt any decisions against changing its positions, and it sought to prevent any kind of military strike to remove the current Syrian regime from power. Indeed, Russia vetoed every decision in this regard-decisions Saudi Arabia strongly opposed. $^{71}$

Iran also poses a threat to Saudi Arabia that is difficult to challenge head-on. Iran has become a major influence in the Middle East especially after the Arab Spring. Iran has not hesitated to show its aversion to the policies of Saudi Arabia, either-especially

available at http://www.alwaleed.com.sa/ar/news-and-media/news/\%D8\%A7\%D9\%84\%D8\%B9\%D8\%B1\%D8 \%A 8\%D9\%8A\%D8\%A9-\%D8\%AE\%D8\%B7\%D8\%A7\%D8\%A8-\%D8\%B5\%D8\%A7\%D8\%AD\%D8\%A8\%D8\%A7\%D9\%84\%D8\%B3\%D9\%85\%D9\%88-\%D8\%A7\%D9\%84\%D9\%85\%D9\%84\%D9\%83\%D9\%8A\%D8\%A7\%D9\%84\%D8\%A3\%D9\%85\%D9\%8A\%D8\%B1-4.

67 O. Alsuhaimi, Saudi Oil Minister Eases from oil prices below \$100, AL-SHARQ Al-Awsat, (September 11, 2014), available at $\mathrm{http}: / /$ aawsat.com/home/article/179966.

68 The Open Letter, supra note 66.

69 R. Mills, Saudi Arabia Plays a Complicated game with Oil Prices, NAT'L, Sept. 21, 2014, available at http://www. thenational.ae/business/energy/saudi-arabia-plays-a-complicated-game-with-oil-prices.

70 J. Solomon \& S. Said, Behind OPEC Decision: Why Saudis Decided Not to Prop Up Oil, Wall St. J., Dec. 21, 2014, available at https://www.wsj.com/articles/why-saudis-decided-not-to-prop-up-oil-1419219182.

71 D. Alweqyan, International Crimes Committed During the Armed Conflict in Syria, 93 CAIRo J. L. \& Econ. 81 (2015). 
regarding the Syrian conflict of 2012. I would argue that Saudi Arabia-as the world's biggest oil supplier-can use this power to affect Russia and Iran economically even if it cannot affect either country politically. The negative impact on both countries was obvious, which led to a significant economic downfall.

According to the WAll StREet Journal, ${ }^{72}$ the US and Saudi Arabia made a deal in King Abdullah's palace on the Red Sea to weaken Russia and Iran economically as a reaction to their stance and support of the Al-Assad regime and the Syrian war. Moreover, the deal contained a full commitment from Saudi Arabia to support the US airstrike against the Islamic State ("ISIS") ${ }^{73}$ as a step to end the conflict in Syria. If such a deal does exist, then Saudi Arabia might manipulate oil prices to affect the world's economy-especially so Russia cannot prevent the US strikes on Syria. Such strikes could provoke anger and resistance from other countries such as Turkey. However, Saudi Arabia claims that it is neither manipulating oil prices, nor controlling over the reduction in oil costs. They refer to several international events that have led to this dilemma, such as a decrease in oil demand from the US, Europe, and Japan. ${ }^{74}$

Prices have not increased as was predicted by the IEA in January $2016 .{ }^{75}$ Instead, prices fell tremendously (below USD 20/B), which led OPEC-Plus (OPEC member states and Russia) to meet in Doha in February 2016 to solve this problem by agreeing to freeze oil production at the January 2016 level to stabilize their economies.

\section{Effects of oil prices in Kuwait}

Kuwait is one of the leading oil exporters (6th place internationally and 3rd among OPEC members). ${ }^{76}$ Kuwait, similar to many other OPEC countries, has been affected by lower oil prices because it depends completely on oil in building its economy.

72 A. Entous \& J. Barnes, Deal with Saudis Paved Way for Syrian Airstrikes, WALL. St. J., Sept. 24, 2014, available at http://www.wsj.com/articles/deal-with-saudis-paved-way-for-syrian-airstrikes-1411605329.

73 C. Whitlock, U.S. Begins Airstrikes Against Islamic State in Syria, WASH. Post, Sept. 23, 2014, available at http://www. washingtonpost.com/world/national-security/us-begins-airstrikes-against-islamic-state-in-syria/2014/09/22/8b677e2642b3-11e4-b437-1a7368204804_story.html. See also Z. Miller, U.S. Launches Airstrike Campaign against ISIS in Syria, TIME, Sept. 22, 2014, available at http://time.com/3419906/u-s-launches-airstrike-campaign-against-isis-in-syria; U.S. Led Task Force Launches 34 Airstrikes Against ISIS in Iraq and Syria, GuARDIAN, Feb. 1, 2015, available at http:/ www.theguardian.com/world/2015/feb/01/us-led-coalition-launches-air-strikes-isis-iraq-syria.

74 B. Fattouh, et al., The Dynamics of the Revenue Maximization-Market Share Trade-Off: Saudi Arabia's Oil Policy in the 2014-2015 Price Fall, 61 OIES Paper: WPM 2 (2015), available at https://www.oxfordenergy.org/wpcms/wpcontent/uploads/2015/10/WPM-61.pdf.

75 IEA Oil Report (2016), available at $\mathrm{https}$ //www.iea.org/data-and-statistics/data-tables?country=WORLD\&energy=Bal ances\&year $=2016$.

76 S. Rithuan, et al., The Impact of Crude Oil Price on Islamic Stock Indices of Gulf Cooperation Council (GCC) Countries: A Comparative Analysis, Munich Personal RePEc Archive 3 (2014), available at https://mpra.ub.unimuenchen.de/56989/1/MPRA_paper_56989.pdf. 
In the GCC meeting for oil ministers, the then Kuwaiti Oil Minister Ali Al-Omair stated that declining oil prices were not a problem because the situation was likely to be a short phase that would pass without major lasting effects on the GCC States. The minister stated that OPEC's decision to maintain the rate of production was the correct move. He clarified that the decision did not mean waging a war of prices, but it is aimed to preserve the organization's quota of the international oil production $(30 \%){ }^{77}$ Al-Omair also declared: "So far, we are confident that prices have not dropped to the extent that makes us call for an emergency meeting." ${ }^{, 78}$ He added that increasing oil production from the US might have had some impact on oil prices, but the prices will begin to rise again after a short period. ${ }^{79}$

I disagree with the policy that this meeting pursued. The GCC is mainly attempting to stabilize the market from low oil prices, while Kuwait should not underestimate the dangerous results from that approach. Its entire economy has been and will be based on oil. Kuwait has no secret agenda in supporting low oil prices, either. Lower prices will markedly affect its budget, and Kuwait, similar to the other petroleum States, should feel alarmed about its economy and begin pursuing other sources of income other than oil. Kuwait still believes there are more years of oil production especially with the discovery of several new oil reserves and international demands. $^{80}$

The crisis also impacted the economy of specific companies and institutions hit by low oil prices. Kuwait Petroleum Corporation ("KPC") is one of the largest oil companies in the world and suffered a negative impact due to the political issues accompanied by reduced oil prices. KPC tried to preserve steady prices when the 2014 price drop occurred with many decisions to maintain long-term price strategy. ${ }^{81}$ They depended on the IEA data to predict prices $^{82}$ because these values are considered the most realistic data available. However, they are subject to uncertainty due to unpredictable daily events. This strategy helped KPC to continue exporting oil without the need to cut production. They continued selling oil in the USD 27-30 P/B range for

77 See Heavy Oil, 39 Alnaft, Kuwait Ministry of Oil 4 (2015), available at http://www.moo.gov.kw/App_Themes/mooEn/ pdf/mag/alnaft39_en.pdf.

78 No Cause for Alarm, supra note 63.

79 See Brent Below $\$ 97$ and Saudi Arabia is not Worried, Al-Hayat, Sept. 12, 2014.

80 Kuwait Says It Has Discovered New Oil Fields, Arabian Bus. Inds. Mar, 24, 2016, available at https://www. arabianbusiness.com/kuwait-says-it-has-discovered-new-oil-field-626138.html.

81 Kuwait Petroleum Corporation, KPC Strategic Planning 2010/2015 (2010), available at https://www.kpc.com.kw/ press/KPCPublications/AnnualReports/AnnualRep2010-eng.pdf.

82 IEA, Medium-term Oil and Gas Markets (June 10, 2014), available at https://webstore.iea.org/medium-term-gasmarket-report-2014. 
several months of 2014 to avoid any political tension in the region from affecting its production. $^{83}$

Oil prices stabilized somewhat in March 2015 at USD 53 P/B, but there was later a crash to USD 47 P/B following a statement by Mr. Al-Omair on uncertainties about oil prices. ${ }^{84}$ The reason for the falling prices is that Kuwait demonstrated uncertainty about oil price stability. There was a deep concern that this crisis would last longer than they predicted. The oil market is similar to the stock market: It is affected by negative statements about strength and stability. However, Kuwait assured the world that it did not intend to harm any OPEC member with these statements. Kuwaiti crude oil prices were stabilized in April 2015 at USD 54 P/B before falling to USD 18 $\mathrm{P} / \mathrm{B}$ by the end of that year. Kuwait then started an abstention plan to preserve its stable economy by eliminating unnecessary expenses. ${ }^{85}$

\section{B. Effects of Saudi Arabia's Action on Some States}

Saudi Arabia's stance on the reduction of oil prices affected other economies. Did Saudi Arabia deliberately decrease oil prices to pressure targeted States? There is no evidence showing that Saudi deliberately manipulated oil price, yet some States such as Iran and Russia continue to accuse it of doing so.

\section{Iran}

Iran suffered dramatically from low oil prices. Commerzbank commodities analyst Carsten Fritsch noted that the decline in oil prices raises serious questions about the desire of Saudi Arabia and some OPEC members to hurt Iran economically - especially when Iran was already managing sanctions for its nuclear program which were weakening its economy. ${ }^{86}$ The continuation of reducing oil prices may eventually lead to a collapse in the Iranian economy - an outcome that Saudi Arabia may have wanted-because Iran would be less able to interfere with other Arab States. Iran operates disruptive groups in many Arab regions including Hezbollah in Lebanon, ${ }^{87}$

83 M. Wood \& O. Alsayegh, Impact of Oil Prices, Economic Diversification Policies and Energy Conservation Programs on the Electricity and Water Demands in Kuwait, 66 ENERGy PoL'y 148 (2014).

84 Id.

85 Al-Omair: The Reduction of Oil Prices Will Have Negative Impact on GCC, Moo Gov. (Mar. 24, 2015).

86 See Oil Plunges Below $\$ 29$ On Prospects of More Iran Crude, China Woes, Gulf Time Bus. Jan 16, 2016, available at https://m.gulftimes.com/content/pdf/Business/Business2016_1_16881800.PDF.

87 T. Juneau \& S. Razavi, Iranian Foreign Policy Since 2001: Alone in the World 125-30 (2013). See also Rola AlHusseini, Hezbollah and the Axis of Refusal: Hamas, Iran and Syria, 31 Third World Q. 803 (2010); A. Samii, A Stable Structure on Shifting Sands: Assessing the Hizbullah-Iran-Syria Relationship, 62 MiddLE E. J. 32 (2008). 
the Assad regime in Syria, ${ }^{88}$ the Shiaa groups in Bahrain, ${ }^{89}$ the Muslim Brotherhood in Egypt, ${ }^{90}$ the government in Iraq ${ }^{91}$ and the Houthis in Yemen. ${ }^{92}$

Thus, Iran was already experiencing political and economic hardship, reflecting "a devastating signal" to the survival of Iranian political power. ${ }^{93}$ Additionally, Georgetown University's political economist Jean-François Seznec stated: "It is really Iran who is getting hurt, and I am wondering to what extent the Saudis are not pursing lower price to bring Iran to the bargaining table."${ }^{.94}$

Iran faces lack of financial liquidity as shown between the lines of the threats to Saudi Arabia. Iran demanded that Saudi Arabia should cease manipulating oil price and help find a solution to reach a stable (and higher) price. Iran needs a price of higher than USD 100 P/B to be economically safe. Indeed, oil prices seem to directly affect the value of Iran's currency. Actually, Iran's Rial has dropped more than 6 percent versus the US dollar, since the OPEC decision not to cut output in $2014 .^{95}$

Former Iranian President Hassan Rouhani declared that low oil prices are a "politically motivated" action taken by Saudi Arabia. He also accused Saudi of perpetrating a "conspiracy against the interests of the region, the Muslim people, and the Muslim world" and concluded that "Iran and the people of the region will never forget conspiracies." 96 This statement shows the tension between the two countries

88 W. Fulton, et al., Iranian Strategy in Syria, Institute for the Study of War and AEI's Critical Threats Project (2013), available at http://www.understandingwar.org/sites/default/files/IranianStrategyinSyria-1MAY.pdf.

89 M. Slackman, The Proxy Battle in Bahrain, N.Y. TımES, Mar. 19, 2011, available at http://www.nytimes.com/2011/03/20/ weekinreview/20proxy.html?pagewanted=all\&_r=0. See also K. Leigh, Bahrain: Caught Between Saudi Arabia and Iran, TıME, Mar. 15, 2011, available at http://content.time.com/time/world/article/0,8599,2058992,00.html.

90 M. Khalaji, Egypt's Muslim Brotherhood and Iran, Washington Institute Policy Analysis, Feb. 12, 2009, available at http://www.washingtoninstitute.org/policy-analysis/view/egypts-muslim-brotherhood-and-iran. See also M. Khalaji, Iran on Egypt's Muslim Brotherhood, PBS, Feb. 25, 2011, available at http://www.pbs.org/wgbh/pages/frontline/ tehranbureau/2011/02/iran-on-egypts-muslim-brotherhood.html.

91 L. Beehner \& G. Bruno, IRAQ: Iran's Involvement in Iraq, Council of Foreign Relations, Mar. 3, 2008, available at https://www.cfr.org/backgrounder/iraq-irans-involvement. See also A. Jafarzadeh, Tehran's Strategic Defeat in Iraq, SPC, Apr. 6, 2010, available at http://spcwashington.com/?p=628.

92 See, e.g., Yemen's Hadi Declares Houthi Power Grab Illegal, Al JAZEera, Feb. 22, 2015, available at http://www. aljazeera.com/news/2015/02/yemen-leader-hadi-leaves-sanaa-weeks-house-arrest-150221090018174.html; Yemen Crisis: UN Demands Houthis Cede Power, BBC News, Feb. 15, 2015, available at http://www.bbc.com/news/worldmiddle-east-31483107; Houthis Take Charge in Yemen, Al AraBIYA, Feb. 6, 2015, available at http://english.alarabiya. net/en/News/middle-east/2015/02/06/Yemen-s-Houthi-to-issue-constitutional-decree.html.

93 Id.

94 Hubbard \& Krauss, supra note 62.

95 M. Moghtader \& R. El Gamal, Iran Oil Minister: The OPEC Decision wasn't Good for All of Us, Reuters, Nov. 30, 2014, available at http://www.businessinsider.com/r-iran-opec-decision-not-good-for-all-members-but-wontprotest-2014-11.

96 T. Barrabi, Iran's Hassan Rouhani: Falling Oil Prices A “Conspiracy” As OPEC Infighting Continues, InT'L Bus. TIMEs, Dec. 10, 2014, available at http://www.ibtimes.com/irans-hassan-rouhani-falling-oil-prices-conspiracy-opec- 
over who will lead the region-especially in such situations like Syria, Yemen, and nuclear programs. However, Saudi Arabia has ignored Iranian threats and taken no serious measures to solve the oil pricing problem (e.g., cutting production). They did not even support the Iranian demands in OPEC. Olivier Jakob, the managing director of Petro Matrix, said that Saudi Arabia has shown no interest in cutting production to increase oil prices. ${ }^{97}$

\section{Russia}

Russia also depends on oil production for a stable economy, while Saudi Arabia has used oil to press Russia. Between 1985 and 1990, the US pressured Saudi Arabia to deliberately decrease oil prices from USD $30 \mathrm{P} / \mathrm{B}$ to USD $12 \mathrm{P} / \mathrm{B}$ to threaten the economy of the then USSR. Such action shook the Soviet's oil business. ${ }^{98}$ Saudi Arabia decreased oil prices and increased oil production from $2 \mathrm{M} / \mathrm{B}$ to $6 \mathrm{M} / \mathrm{B}$ in $1986 .{ }^{99}$

In 1998, Saudi Arabia managed to cause oil prices to drop to USD 12 P/B from USD 25 P/B, which caused Russia to go into debt. ${ }^{100}$ Saudi Arabia used the same weapon again in 2014 to manipulate oil prices and weaken the Russian economy. At that time, the US had a stronger position against Russia internationally to control its stance toward the Syrian crisis with Saudi Arabia. In particular, the US prevented Russia from casting its veto in the Security Council to adopt a decision against the AlAssad regime regarding Syria's acts of mass atrocity on innocent civilians, but the US could not achieve the same stance when it came to strike the Syrian regime due to the Russian veto.

According to Gray Ross, ${ }^{101}$ political considerations are the impetus to falling oil prices. He stated: "It is convenient that this is occurring at a time when Iran is getting stronger and when Russia, a huge oil exporter, has been a thorn in the side by supporting Assad."102 Russia faced many economic challenges in 2014-2015 such as

infighting-continues-1747147.

97 A. Lawler, et al., Saudi Block OPEC Output Cut, Sending Oil Price Plunging, Reuters, Nov. 27, 2014, available at http://www.reuters.com/article/2014/11/27/us-opec-meeting-idUSKCN0JA0O320141127.

98 T. Apenzeller, The End of Cheap Oil, Nat'l Geo. Mag. 5 (2004). See also P. Schweizer, Victory: The Reagan Administration's Secret Strategy that Hastened the Collapse of the Soviet Union (1994).

99 D. Reynolds \& M. Kolodziej, Former Soviet Union Oil Production and GDP Decline: Granger Causality and The Multi-Cycle Hubbert Curve, 30 EnERgy ECo. 274 (2008).

100 A. Topf, Did the Saudis and the US Collude in Dropping Oil Prices, OrL Price.com, Dec. 23, 2014, available at http:// oilprice.com/Energy/Oil-Prices/Did-The-Saudis-And-The-US-Collude-In-Dropping-Oil-Prices.html.

101 A petroleum expert and chief executive in the PIRA Energy Group.

102 Oil firms Gain as Diesel Sales Rises 87\% within a Fortnight, Bus STAND., Oct. 17, 2014, available at https:// www.business-standard.com/article/companies/oil-firms-gains-on-diesel-sales-rise87-per-cent-within-a-fortnight114101600477_1.html. 
rapid depreciation of the Ruble, a decline in the Ruble's value versus the US dollar, ${ }^{103}$ exclusion from international capital markets, inflation, and domestic budgetary pressures. Russian economic growth slowed to 0.7 percent in 2014 before contracting sharply by 3.7 percent in 2015. The US and the EU sanctions on Russia (due to its interference in Eastern Ukraine) had a huge effect on the Russian economy-especially due to a dramatic drop in oil prices, since oil is a major source of export revenue for Russia. $^{104}$

Russia also needs oil prices to remain above USD 80 P/B to weather any further challenges to its economic stability. The Russian Minister of Finance Anton Siluanov stated that Russia should maintain a stable budget to manage the current conditions. He reiterated the need to increase oil price to lift the economy to a safer level. ${ }^{105}$ OPEC's decision not to cut the output of its members in 2014 led to a crash in the value of Ruble including a decrease of 3.6 percent against US dollar and Euro. ${ }^{106}$ This decline in Ruble is the largest devaluation since the huge drop in oil prices in 1998. Moreover, the Russian Central Bank had difficulty in strengthening the currency and raised interest rates to 6.5 percent. The chairman of the Russian Central Bank Sergei Shvetsov said: "The situation is critical." "107 The low value of Ruble affected Russia's economy and its political position in the international community where maintaining a stable economic position is necessary.

Venezuelan President Nicolas Madura asked a remarkable question: "What is the reason for the United States and some US allies wanting to drive down the price of oil?" To which he then provided an equally remarkable answer: "To harm Russia." "This public statement about an "international oil game" in which the US and Saudi Arabia attempt to harm Russia seems compelling. First, Venezuelaas an oil producing country and an OPEC member-was protecting its interests by expressing its concerns about any manipulations of oil prices that might have crashed its economy. Second, harming Russia economically by using the "oil weapon" would be easier for the US and Saudi Arabia than confronting Russia politically or militarily.

\footnotetext{
103 Lawler, et al., supra note 97.

104 R. Nelson, U.S. Sanctions and Russia's Economy, CRS Report 4 (R43895: Feb. 17, 2017), available at https://fas.org/ sgp/crs/row/R43895.pdf.

105 See OPEC Decision will Keep Oil Prices Low \& Hit Russia, Iran, US- Experts, Russia Today, Nov. 28, 2014, available at http://rt.com/business/209579-opec-oil-supply-russia.

106 See Russian Ruble Hits Historic Lows Against Dollar, Euro on OPEC Decision, Radio Free Europe, Nov. 27, 2014, available at $\mathrm{http} / /$ www.rferl.org/content/russia-ruble-historic-lows/26714020.html.

107 E. Reguly, Putin's Russia is the Crude Crash Wild Card, Global \& MaIL, Dec. 19, 2014, available at http://www. theglobeandmail.com/news/world/putins-russia-is-the-crude-crash-wild-card/article22169580.

108 Topf, supra note 100.
} 
Third, Saudi Arabia has been attempting for years to change the regime in Syria and to reach a solution in the Security Council without getting hit by the Russian veto for the sake of Syrian civilians who are suffering from acts of massacre and atrocity perpetrated by the Syrian government that may reach a phase of genocide. ${ }^{109}$ Fourth, playing with oil prices would achieve the goals of the US and Saudi Arabia in terms of the position of Iran. The US and Saudi Arabia could more easily control the Middle East by harming Iran's economy.

Russia, as a permanent member of the UN Security Council, has strongly defended Syria's position in the UN. Russia has vetoed any attempt to adopt a decision against Syria's Al-Assad regime in the past few years because Syria represents Russian influence in the Middle East. Thus, implementing a solution for Syria has been difficult because Saudi Arabia could not stand against Iran or Russia in an explicit political stance. Russia has great political weight in the international community, whereas Iran is a dominant force in the Middle East. Iran, especially in its recent control over Yemen, started a war against Saudi Arabia using the Houthis. Iran's actions have led Saudi Arabia to create a coalition to regain the legitimacy of the Yemeni president. ${ }^{110}$

Steve LeVine observed that the only winner in the low oil price game is Saudi Arabia because it is the only player in the 'game' that can maintain its budget in the shadow of low prices. ${ }^{111}$ However, the Russian and Iranian response may be harsh because both may restrict Saudi Arabia's influence in the Middle East as the Arab leader. $^{112}$

\section{Conclusion}

Reduced oil prices are a notable topic. Oil prices are affected by many factors both economic and political. Crude prices fell in 2014 due to slowing EU economic

109 Alweqyan, supra note 71 , at 77 .

110 Id.

111 S. Levine, The Real Reason Saudi Arabia Can Afford a Price War Against US Shale, QuARTz, Dec. 12, 2014, available at http://qz.com/311179/the-real-reason-why-saudi-arabia-can-afford-a-price-war-against-us-shale. See also A Lower Price Will Boost: The World Economy and Harm Some Unpleasant Regimes, But There Are Risks, Economist, Oct. 25, 2014, available at $\mathrm{http} / /$ www.economist.com/news/leaders/21627619-lower-price-will-boost-world-economy-andharm-some-unpleasant-regimesbut-there-are; T. Macalister, Low Oil Price Means Anxiety for OPEC as US Flexes its Muscles, Guardian, Oct. 18, 2014, available at http:/www.theguardian.com/business/2014/oct/19/oil-price-us-opecbrinkmanship-shale-gas.

112 Bazzi, supra note 64. 
performance, rising US shale oil production, and poor global growth rates. OPEC, under the influence of Saudi Arabia, did not cut production. Rather, OPEC member States insisted on finding solutions for price recovery other than decreasing production which caused the oil price to collapse. This development coincided with the tense military situation in Ukraine, economic sanctions against Iran and Russia, and the civil war in Syria. This was only slightly before the Venezuelan bankruptcy crisis as well.

The sudden downfall of oil price in 2014 affected many countries including both exporters and importers. It especially changed the political map of countries such as Russia and Iran. ${ }^{113}$ The WTO further reported a decrease in oil prices to have a sharp impact on the global economy. According to the multilateral agreements of the WTO, member States can always increase their oil exports because this falls within the general principle of liberalizing foreign trade from various restrictions; however, countries may not reduce them except under certain conditions.

Importantly, Saudi Arabia denied allegations of intentionally reducing oil prices. It insisted that Saudi economy was also affected by this crisis. Also, Saudi Arabia intended to push prices to a stable level. The current Saudi oil policy is badly affecting the US production of shale oil, which Americans use for petroleum self-sufficiency.

Furthermore, the harm to Iran and Russia was greater than the harm to the US. While the US did lose shale oil production, it gained crude oil imports. Russia and Iran lost both political and economic leverage especially with American policy that imposed economic and financial sanctions on both countries. ${ }^{114}$ Saudi Arabia and other GCC members are content to bear heavy financial losses until Iran changes its policies in the region. Indeed, Iranian policies are a threat to the Arab world's security, economic interests, and stability.

The 2014 crisis had a major and continuous effects until today. The crisis led to a significant decrease in the production of some countries, such as Iraq, hit by the ISIS occupation of Mosul controlling important oil wells. ${ }^{115}$ Several studies were issued anticipating a contraction in oil market between 2020 and 2021, ${ }^{116}$ especially with

113 D. Gros, The Price of Oil and Soviet/Russian Aggressiveness, European Pol’y Stud. 1 (2015). See also M. Reza \& M. Raeisian, Iranian-Oil Free Zone and International Oil Prices, 45 ENERgy ECon. 1 (2014).

114 A. Khlebnikov, Iran, Russia, and the impact of US sanctions, Middle East Institute Policy Analysis. July 17, 2019, available at $\mathrm{https}: / /$ www.mei.edu/publications/iran-russia-and-impact-us-sanctions.

115 See ISIS has lost control of its last oil wells in Iraq, REUTERS, Sep 28, 2016, available at https://www.businessinsider. com/r-islamic-state-loses-control-of-last-oil-wells-in-iraq-oil-ministry-2016-9.

116 R. Tol, A Cost-Benefit Analysis of The EU 20/20/2020 Package, 49 EnERgy PoL'y 288 (2012). See also M. Filippidis, et al., Oil Price Shocks and EMU Sovereign Yield Spreads, 86 ENERgy Econ. 104656 (2020); N. Kose \& E. Unal, The Impact of Oil Price Shocks on Stock Exchanges in Caspian Basin Countries, 190 ENERGY 116383 (2020). 
continues reduction in current oil prices. It means lower demand for oil which may cause the following:

- Deterioration in payment balances for some countries such as US and China. This expected to be the case if prices stayed still or fall below current levels. ${ }^{117}$

- Impediment in encouraging renewable energies which may grant from waterfalls, Solar, wind and geo-heat sources.

- Reduction in gas prices in regions where gas pricing contracts are linked to crude oil or its products, such as Asia, in addition to a decrease in the American gas prices, resulting in a reduction of European gas market, as well. ${ }^{118}$

- Forcing additional taxes on consumers to reduce pressure on countries regarding low oil price to finance necessary public uses such as, for example, calling for a federal tax increase to help raise the "Highway Trust Fund" in the US. ${ }^{119}$

On one hand, some economic sectors are benefited from low oil prices, including: land and air transport, electricity, refineries, iron, aluminum factories, and cement. On the other hand, this reduction has negative repercussions on the oil exporting countries, where they may face enormity of public budget deficit.

Despite the continuous decline in the oil price until today, OPEC is still trying to maintain a competitive price for oil compared to other energy sources. This is in addition to maintaining its oil market shares.

Received: February 1, 2020

Modified: March 30, 2020

Accepted: May 15, 2020

117 P. Alexander \& L. Poirier, Did U.S. Consumers Respond to the 2014-2015 Oil Price Shock? Evidence from the Consumer Expenditure Survey, 41 ENERGY J. 1 (2020).

118 Tol, supra note 116, at 290.

119 Alaa Alkhatib, The Sharp Drop in Oil Prices 115 (Arabic Inst. ed. 2015). See also Alexander \& Poirier, supra note 117 , at $13-4$. 
